\title{
Notes on the vocalizations of Rufous-capped Warbler (Basileuterus rufifrons)
}

Peter Boesman

In the following we briefly analyze and compare voice of the different races of Rufouscapped Warbler (Basileuterus rufifrons). We also try to quantify the extent of any vocal differences using the criteria proposed by Tobias et al. (2010), as a support for taxonomic review. We have made use of sound recordings available on-line from Xeno Canto (XC).

An overview of song per race, illustrated with sonograms:

Southern Yellow-bellied birds: mesochrysus/delattri (no recordings available from Coiba, actuosus)

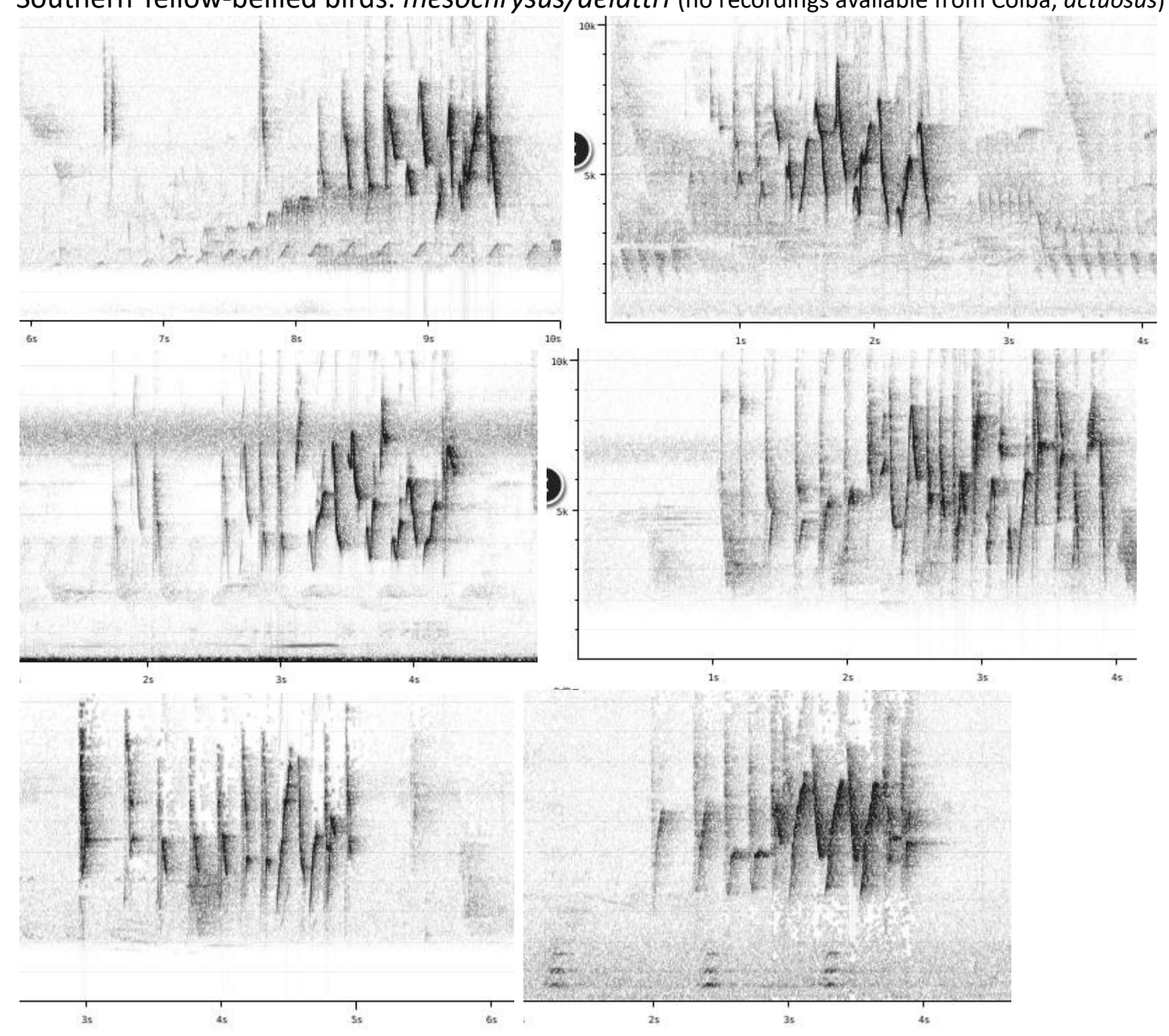




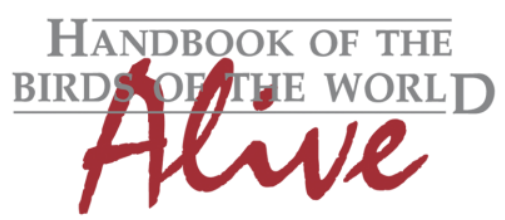

Northern Yellow-bellied birds: salvini
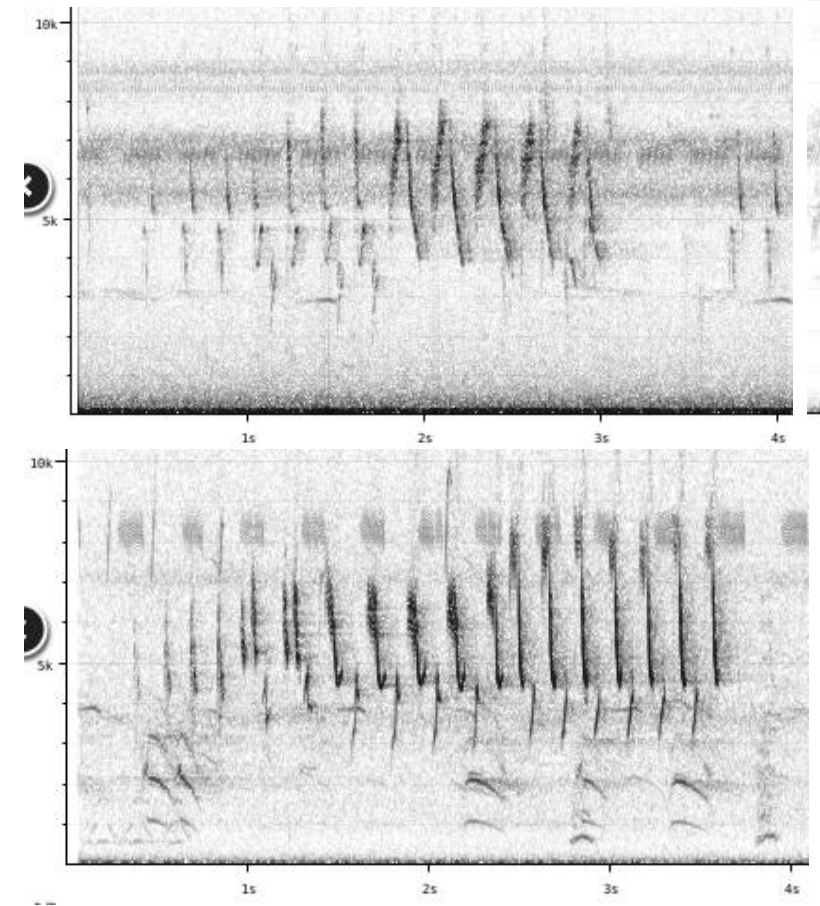

Other races in Mexico (White-bellied birds)

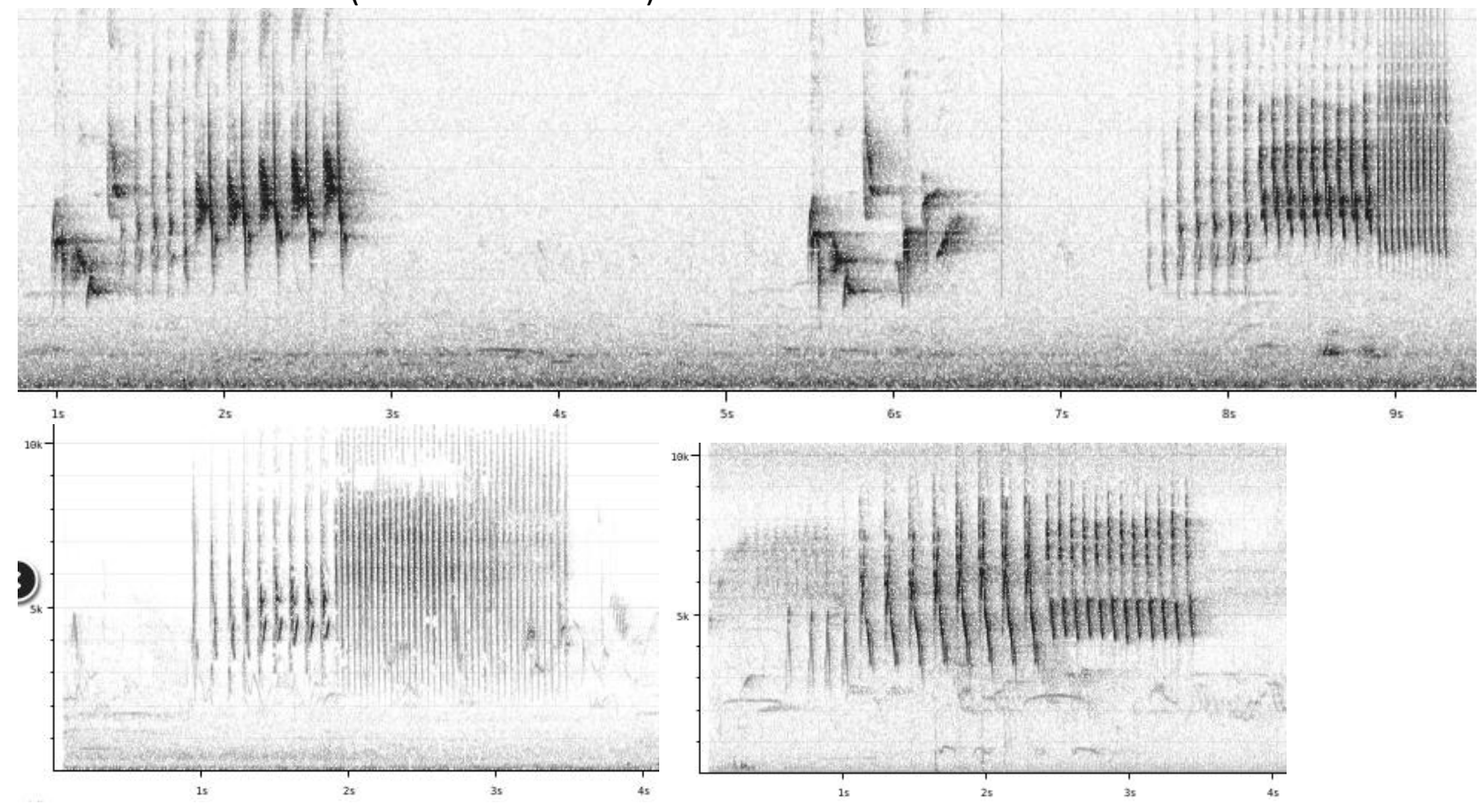




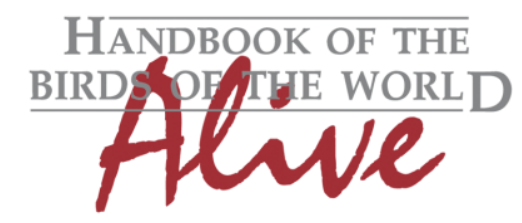

\section{ORNITHOLOGICAL NOTES}
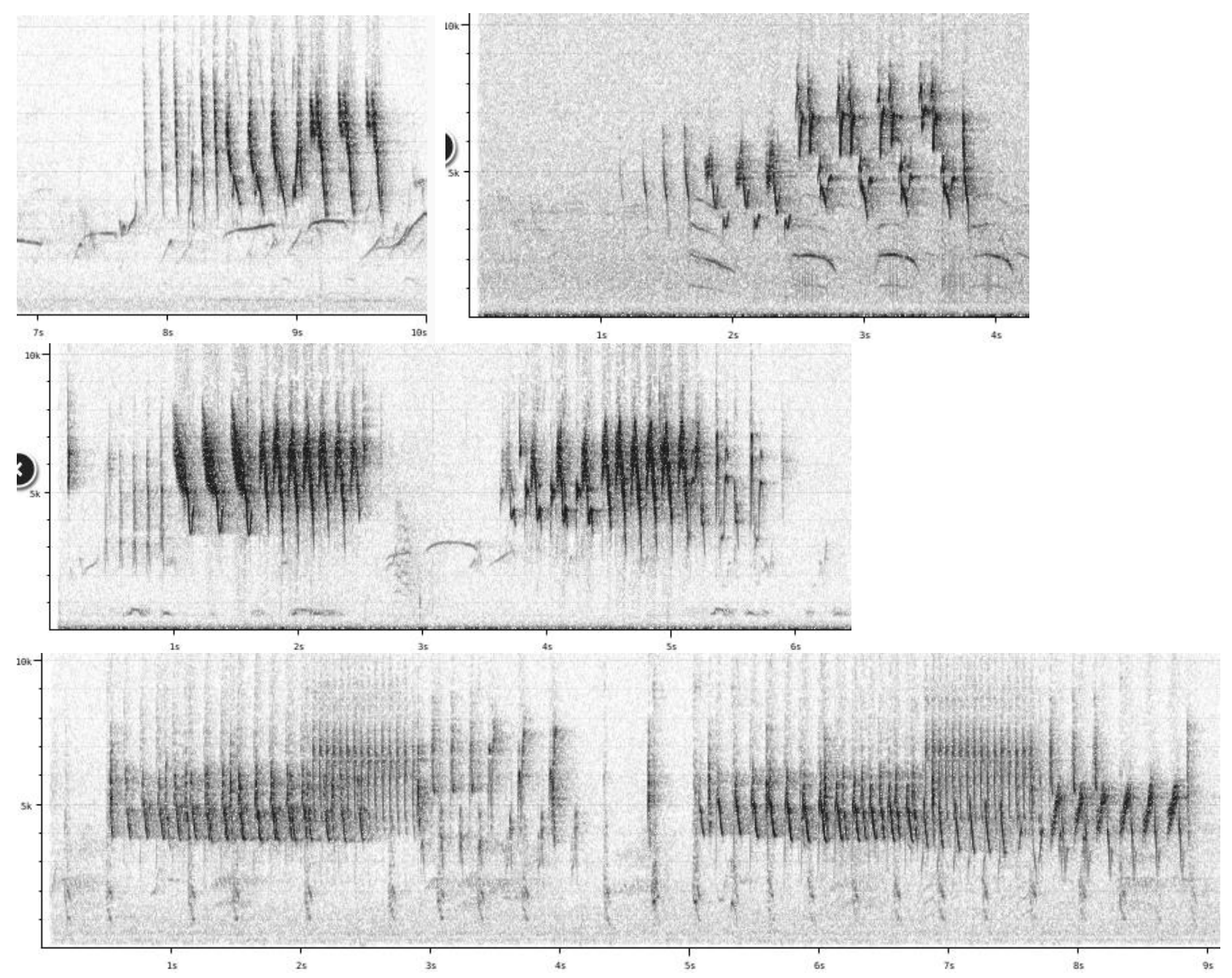

It is clear that typical song of northern races contains 2-3 series of repeated identical notes (repeats are minimum 3 times, but often 4, 5, 6 times or even more).

Southern races (mesochrysus/delattri) typically don't have repeated notes (in some cases at most a note repeated up to 3 times). The pattern of repeated notes occurs however increasingly in the northern part of delattri (e.g. Honduras). The following is an example of the highest number of repeats found in Honduras:

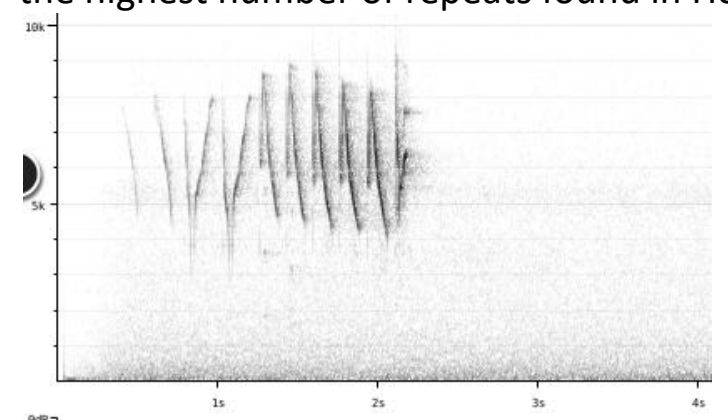

while other examples in Honduras hardly show repeated notes.

There is thus a somewhat clinal change in song, or at least a broad area of transition, which does not coincide with the white-bellied vs yellow-bellied plumage change. While northern races (white-bellied races) including yellow-bellied salvini have a song with several series of repeated notes, southern yellow-bellied races lack such repetitions, but both song patterns 
occur in race delattri.

This note was finalized on 27th June 2016, using sound recordings available on-line at that moment. We would like to thank in particular the sound recordists who placed their recordings for this species on XC.

\section{References}

Tobias, J.A., Seddon, N., Spottiswoode, C.N., Pilgrim, J.D., Fishpool, L.D.C. \& Collar, N.J. (2010). Quantitative criteria for species delimitation. Ibis 152(4): 724-746.

\section{Recommended citation}

Boesman, P. (2016). Notes on the vocalizations of Rufous-capped Warbler (Basileuterus rufifrons). HBW Alive Ornithological Note 379. In: Handbook of the Birds of the World Alive. Lynx Edicions, Barcelona. (retrieved from http://www.hbw.com/node/1252935 on 30 November 2016). 